\title{
Effect of Nozzle Angle to Combustion Characteristic in Biodiesel Burner
}

\author{
Latip Lambosi $^{1,}$, , Amir Khalid ${ }^{1, b}$, Bukhari Manshoor ${ }^{1, c}$, Shahrin Hisyam ${ }^{1}$, \\ Lo Kok Hao ${ }^{1}$
}

\author{
${ }^{1}$ Combustion Research Group (CRG), Centre for Energy and Industrial Environment Studies \\ (CEIES), UniversitiTun Hussein Onn Malaysia, Parit Raja, BatuPahat, 86400 Johor, Malaysia \\ alatiplambosi@gmail.com, bamirk@uthm.edu.my, 'bukhari@uthm.edu.my
}

\begin{abstract}
Keywords: Biodiesel, Burner Combustion, Mixture Formation, Spray characteristic, Flame Development, Emission Characteristic
\end{abstract}

\begin{abstract}
The increasing effort on the environmental impacts of fossil fuel based power generation has led to increased research with the aim of reducing emissions and improving combustion efficiency by turning to alternative fuel such as biodiesel. But the hazardous emission caused by biodiesel is still a problem that need to tackle. One of way to achieve this is by choosing the correct nozzle characteristic. In the current study, the effect of nozzle angle on mixture formation and combustion characteristic are investigate using air-assisted fuel atomizing biodiesel burner. The nozzle angle that was used are $\theta=45^{\circ}$ and $50^{\circ}$. The results show with nozzle $45^{\circ}$ produce lower spray penetration, but higher spray angle and spray area compare to nozzle $50^{\circ}$. The result are similar on flame development. For the emission characteristic, theCarbon Monoxide (CO) and Hydro Carbon (HC) emission had a strong reduction by using nozzle with $45^{\circ}$ angle compare to $50^{\circ}$ angle.
\end{abstract}

\section{Introduction}

The increasing focus on the environmental impacts offossil fuel based power generation has led to increasedresearch with the aim of reducing emissions andimproving combustion efficiency. Much of this work is drivenby the increasing interest into alternative fuels such asbiodiesel. The use of biodiesel is rapidly expandingaround the world, making it imperative to fully understand theimpacts of biodiesel combustion process and pollutantformation. Biodiesel fuel is defined as mono alkyl esters oflong-chain fatty acids derived from renewable lipid feedstocks, such as vegetable oils or animal fats, for use in diesel engines and liquid burners[1].

The strategies to reduce these emissions are generally direct contrary, thus these are in a trade-off relationship. One of the easy, cheap and effective methods for cleaner combustion is by choosing the right nozzle characteristic. Based on the literature review, the important factor in direct injection diesel engines is the quality of the diesel spray. An improvement in the air fuel mixing leads to a better combustion process that results in higher performance, but also modifies pollutant emissions. The spray characteristics are strongly influenced by the nature of the flow inside the injection nozzle hole[2]. Also, studies that start with different nozzle geometries and try to understand the whole process from nozzle flow up to the combustion and formation of pollutants through the air-fuel mixing and vaporization are very limited[3].

Several experimental studies on nozzle characteristic of biodiesel fuel on mixture performance and combustion characteristic have been conducted because of its advantages in choosing the right nozzle that suitable for fuel burner. In a burner, specific type of nozzle can give different geometrical and dimension. Burner nozzle geometry is at issue in spray characteristics and therefore atomization behaviour. Which are very important for burner performance and pollutant formationsuch as Nitrogen Oxide (NOx), Carbon Oxide (CO), Carbon Dioxide (CO2), and Hydro Carbon (HC) from the combustion processIn this experimental work, the effect of nozzle angle on mixture formation and combustion characteristic are investigateusing air-assisted fuel atomizing burner. 


\section{Methodology}

The study used three kinds of biodiesel fuel blends and diesel fuel as a based line. Crude palm oil (CPO) was used to produce the biodiesel blending varied from 5vol \%( B5) - 15vol \%( B15). The biodiesel blends was prepared usingbiodiesel blending machine. Figure 1 shows the schematic diagram of the experiment and the nozzle angle for the biodiesel fuel injector that being used. The distance between the camera and injector is $385.50 \mathrm{~cm}$ and the distance between injector and black screen is $91.5 \mathrm{~cm}$. The experiment starts by injecting the fuel, water and air into the injector. The injector system uses fuel-air internal rapid mixing concept.The premixing injector was firstly designed by Y. Kidoguchi[4]. The air is pressurized at 0.35 bar. The fuel flow rate and water flow rate are controlled by flow meter and speed controller. Fuel-water-air is mixed at mixing chamber. Then, the mixtures are sprayed out from the nozzle. The mixtures will be ignited using blow torch. The spray and flame image is captured by using Digital Single-Lens Reflex (DSLR) camera of Canon EOS 550D. Figure 2 shows the spray characteristic and flame development which include flame length, flame angle and flame area is analysed through Solidworks.Gas analyser Testo 350 are used to measure the chemical substances in the emission gas.

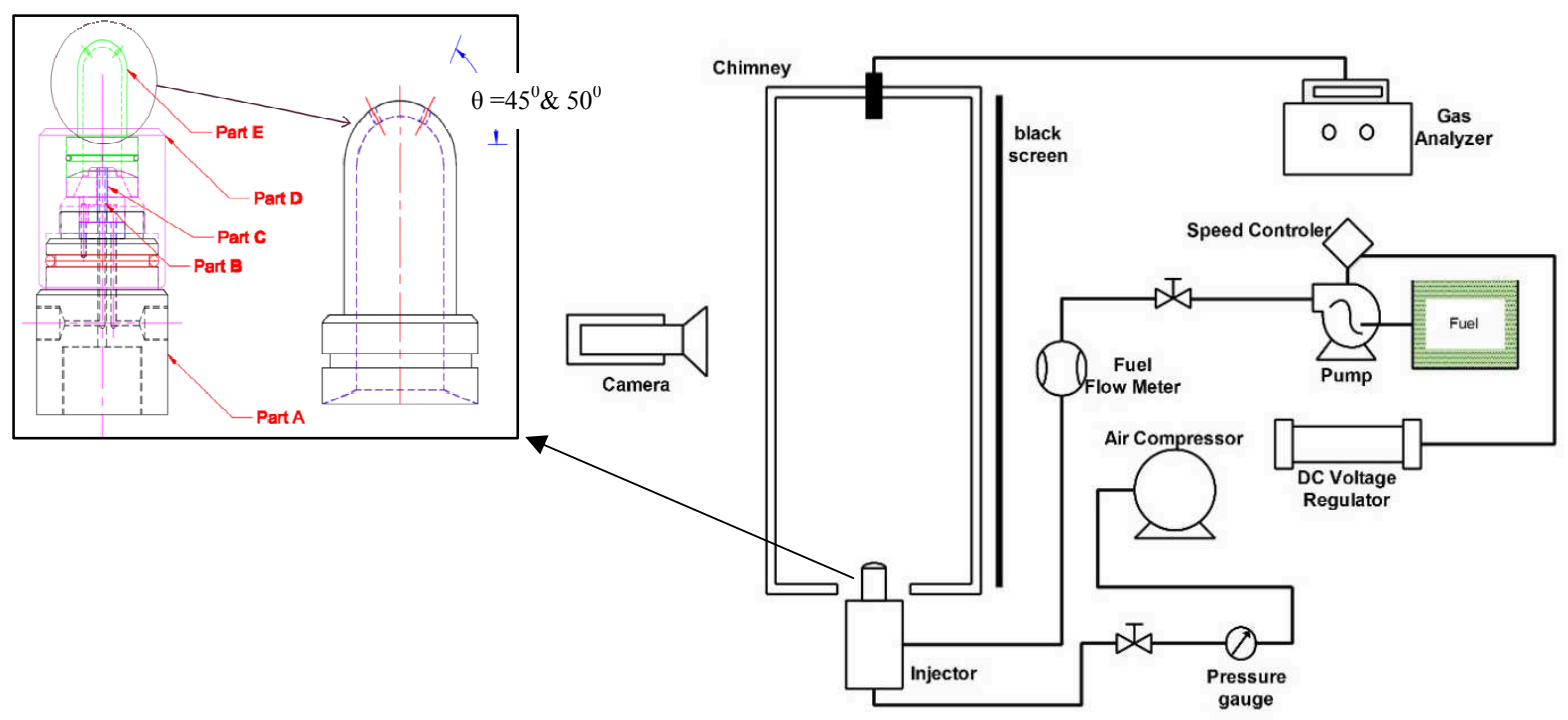

Figure 1: Schematic diagram of biodiesel burner

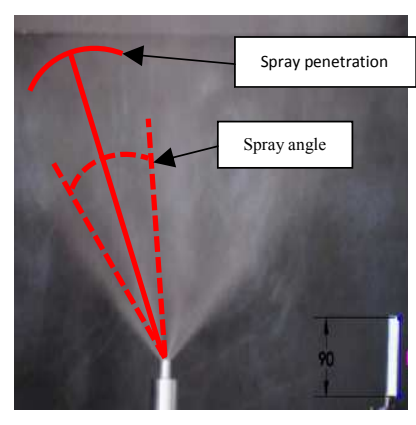

(a)

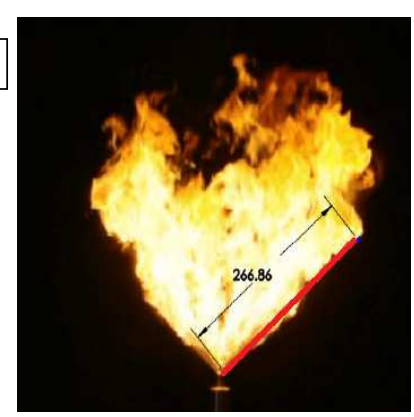

(b)

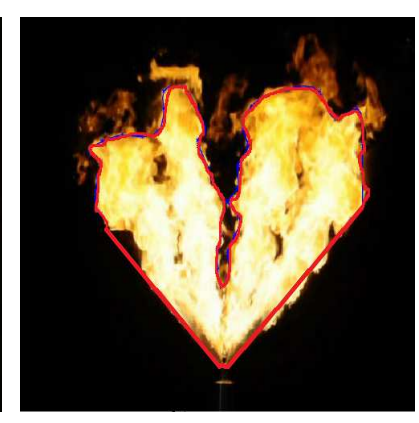

(c)

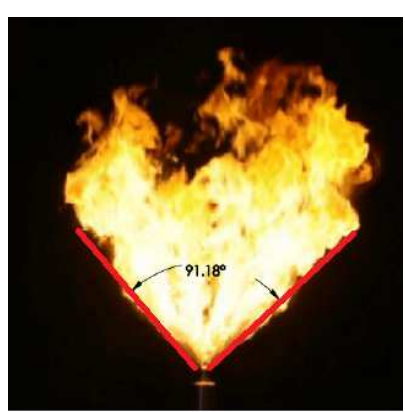

(d)

Figure 2: (a) spray characteristic, (b) flame length, (c) flame area, (d) flame angle

\section{Result and Discussion}

Effect of Nozzle Angle on Mixture Formation and Flame Development. Figure 2 shows the comparison of spray characteristic for the nozzle $45^{\circ}$ and $50^{\circ}$. As seen in figure 1 , the overall trend is the $50^{\circ}$ nozzle are producing higher spray at all points of equivalent ratio compared to $45^{\circ}$ nozzle. There is only a slight reduction in spray angle as the equivalent ratio is increased. But $45^{\circ}$ nozzle still produced larger spray angle compared to $50^{\circ}$ nozzle. This trend can also be observedin spray 
area for both nozzles. Whereas the spray area for $45^{\circ}$ nozzle are larger. For the spray characteristic, in both nozzle B15 show the highest value in the spray area and spray penetration followed by B10, B5 and Diesel. When the biodiesel content is increase in the fuel blends, the viscosity of fuel also increase causing the nozzle flow rate to increase[5].

Figure 3 shows the comparison of flame characteristic for the nozzle $45^{\circ}$ and $50^{\circ}$. the overall trend is the $45^{\circ}$ nozzle are produced higher flame length at all point of equivalent ratio compared to $50^{\circ}$ nozzle. For the flame characteristic there is a minor increment on flame angle as the equivalent ratio is increased. This trend can also be notice on flame area for both nozzle. Although flame area for $45^{\circ}$ nozzle are larger. Opposite from the spray characteristic result, B15 show the lowest value in term of flame area and flame length for both nozzle. This is also may cause by the increase of viscosity in fuel. As the nozzle flow rate to increase its delivers more fuel in larger droplet size and causing poor atomization. With wider flame angles and flame area show that nozzle $45^{\circ}$ have better atomization and produce smaller fuel droplet size. It is sometimes assumed that the smallest droplet size of fuel is the most desirable to produce the quietest and most efficient combustion. One other reason the mixture that with higher content of the biodiesel on both nozzle shows that have the lowest flame length, flame area and the flame area for both nozzles compared to diesel since the flash point is higher for biodiesel. Because with the increase in flash point, the harder for the flame to ignite.

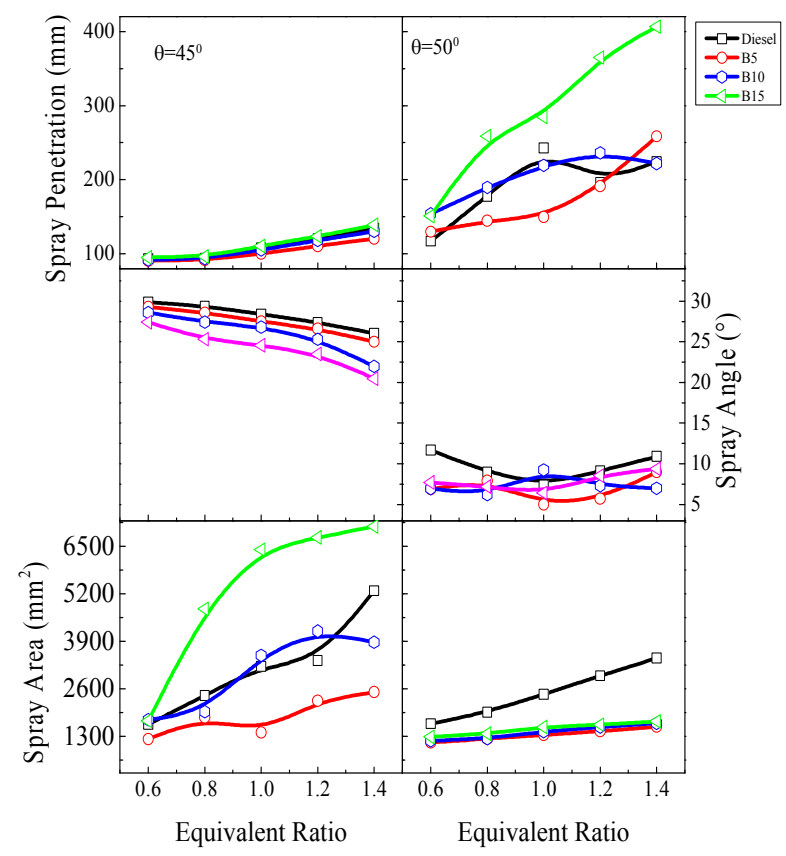

Figure 2: Spray characteristic of biodiesel and two different nozzle angle.

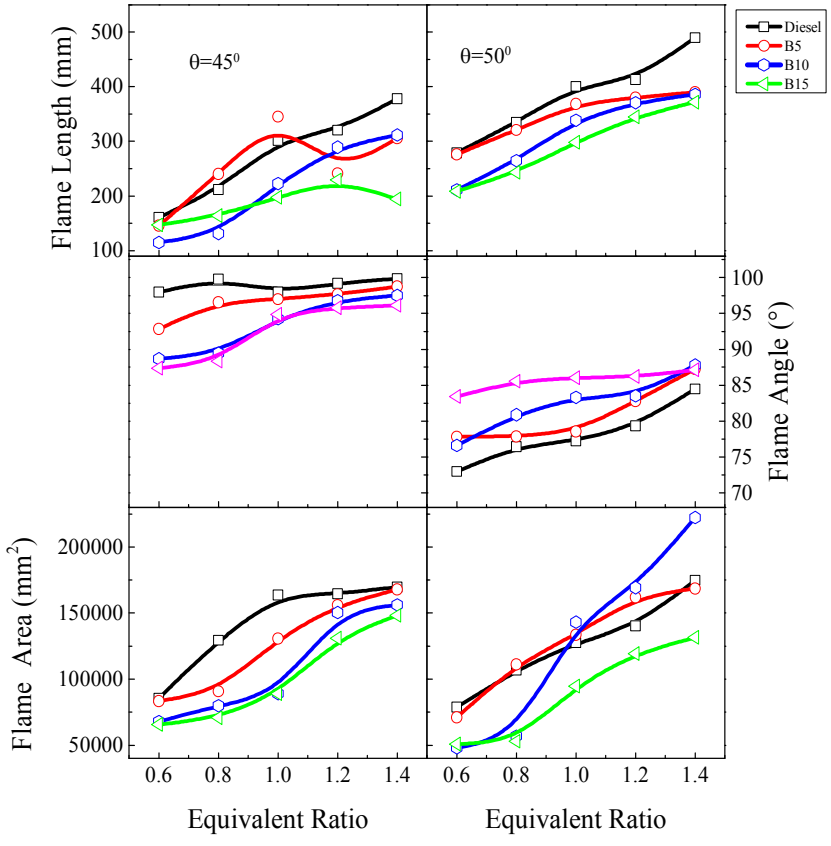

Figure 3: Flame characteristic of biodiesel and two different nozzle angle.

Emission Characteristic.Figure 4shows the comparison of emission characteristic between nozzle $45^{\circ}$ and $50^{\circ}$. For both nozzle, as the equivalent ratio increase, the NOx value also increase. This is caused by the increase of exhaust temperature shown in the graph. B15 produced the highest NOx emissionand exhaust temperature followed by B10, B5 and Diesel. NOx gases are produced when the combustion temperature is too high. This shows that the higher the biodiesel content in the fuel blends, the higher the NOx emission produced[6-8].

As for the $\mathrm{HC}$, the rate of $\mathrm{HC}$ emissions from biodiesel fuel is lower than the rate of $\mathrm{HC}$ emissions from diesel fuel. In the case of equivalence ratio is rising, it will cause more fuel introduced to the combustion process and more fuel are left unburnt causing the $\mathrm{HC}$ value to increased.For the $\mathrm{CO}$ emission. It shows that diesel have the highest emission and followed by B5, $\mathrm{B} 10$ and B15.In the combustion process, the addition of oxygen content in biodiesel and can cause 
complete combustion to reduce $\mathrm{CO}$ emissions. The higher the biodiesel content in the fuel blends, the lower the $\mathrm{CO}$ emission become.

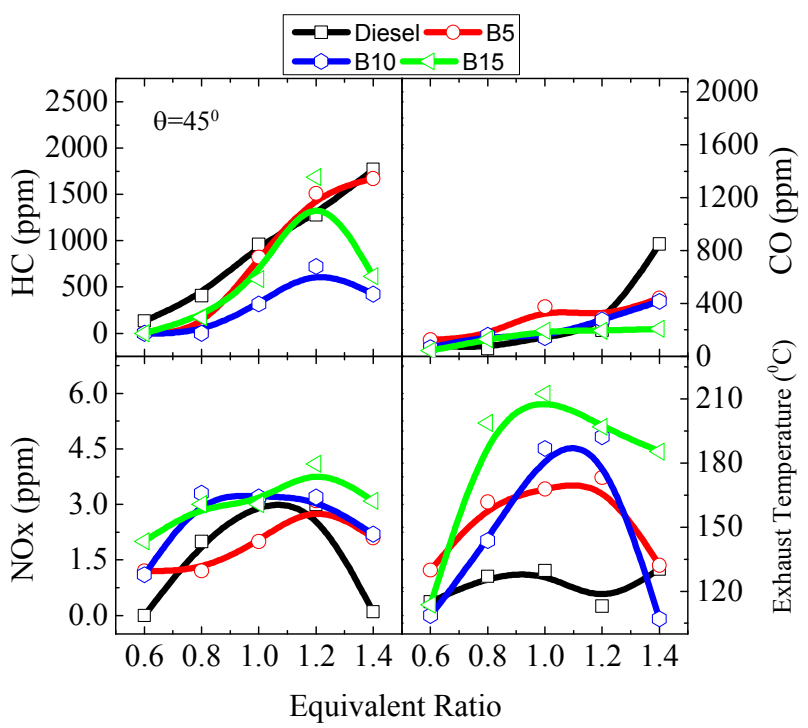

(a)

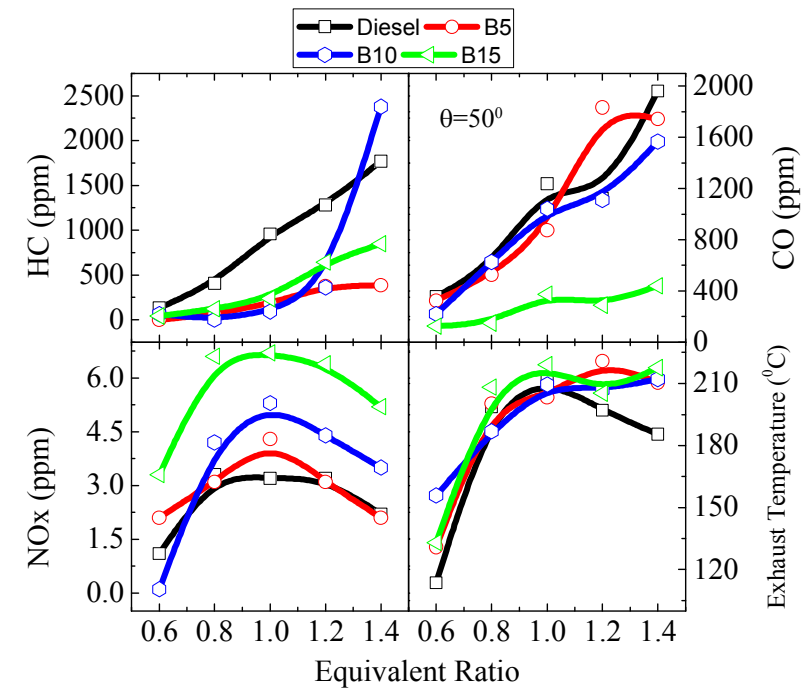

(b)

Figure 4: Emission characteristic of biodiesel burner,(a) $\theta=45^{\circ}$, (b) $\theta=50^{\circ}$,

By comparing emission on both results, nozzle $45^{\circ}$ show a strong reduction in CO and HC. This shows that nozzle $45^{\circ}$ produces more complete combustion compare to nozzle $50^{\circ}$. Corresponding to the on mixture formation and flame development before, with wider spray angle and spray areashows that nozzle $45^{\circ}$ have better atomization and produce smaller fuel droplet size. The smallest droplet size of fuel is the most desirable to produce the quietest and most efficient combustion. But at a certain condition, a long flame or spray angle too wide for the burner air pattern is not suitable, because it may lick the heating surface of the burner and cause sooty combustion or carbon build up in the combustion chamber[3]. So we must choose a proper choice of spray angle.

\section{Conclusion}

An experimental investigation on the effect of nozzle angleofcombustion characteristic in biodiesel burner had been carried out. The following result areobtained by this study.

1. High biodiesel content in fuel blends can produce high spray penetration and spay area, but due to the increase of viscosity of fuel. But it has the exact opposite effect on flame development. Higher biodiesel content also produces high exhaust temperature and Box emission, but low $\mathrm{CO}$ emission.

2. Nozzle $45^{\circ}$ produces lower spray penetration, but higher spray angle and spray area compare to nozzle $50^{\circ}$. The result is similar to flame development.

3. The $\mathrm{CO}$ and $\mathrm{HC}$ emission had a strong reduction by using nozzle with $45^{\circ}$ angle compare to $50^{\circ}$ angles. This cause better atomization and produce smaller fuel droplet size, thus it promotes more complete combustion process that reduce the emission gases.

\section{Acknowledgment}

The author would like to thank the Universiti Tun Hussein Onn Malaysia for supporting this project under the Malaysia Technical University grants (MTUN) vot C010. 


\section{References}

[1] Amir Khalid, Norazwan Azman, Hanis Zakaria, B. Manshoor, Izzuddin Zaman, Azwan Sapit, Mutalib Leman, "Effects of storage duration on biodiesel properties derived from waste cooking oil", Applied Mechanics and Materials, Volume 554, 2014, Pages 494-499, DOI: 10.4028/www.scientific.net/AMM.554.494

[2] C. Bae, J. Yu, J. Kang, J. Kong, and K. O. Lee, "Effect of Nozzle Geometry on the Common-Rail Diesel Spray," SAE Pap. 2002-01-1625, 2002.

[3] J. Charles E. Baukal, The John Zink Combustion Handbook. Taylor \& Francis, 2010.

[4] T. Yatsufusa T. Kumura, Y. Nakagawa and Y. Kidoguchi, "Advantage of using water emulsified fuel on combustion and emission characteristics," Proc. Eur. Combust. Meet. , pp. 1-6., 2009.

[5] Amir Khalid, N.Tamaldin, M. Jaat, M. F. M. Ali, B. Manshoor, Izzuddin Zaman, "Impacts of biodiesel storage duration on fuel properties and emissions", Procedia Engineering, volume 68, 2013, Pages 225 - 230, Elsevier, 2013, DOI: 10.1016/j.proeng.2013.12.172.

[6] Amir Khalid, M.D. Anuar, Yusri Ishak, B. Manshoor, Azwan Sapit, Mutalib Leman, Izzuddin Zaman, "Emissions characteristics of small diesel engine fuelled by waste cooking oil", MATEC Web of Conferences, Volume 13, 2014, Article number 06006, DOI: $10.1051 /$ matecconf/20141306006.

[7] [W. C. M. Sekaran, "Transient State Fuel Injection - A New Concept with Different Fuel Combinations," in Interdisciplinary Research and Development, 2011, no. June, pp. 461467.

[8] Hafis, S.M., Ridzuan, M.J.M., Farahana, R.N., Ayob, A., Syahrullail, S., 2013. Paraffinic mineral oil lubrication for cold forward extrusion: Effect of lubricant quantity and friction, Tribology International, Volume 60, Pages 111-115. 